\title{
BEBAN KERJA SUBYEKTIF DAN OBYEKTIF TENAGA FARMASI RAWAT JALAN DI RUMAH SAKIT
}

\author{
SUBJECTIVE AND OBJECTIVE WORKLOAD PHARMACEUTICAL WORKER OUTPATIENT IN THE \\ HOSPITAL
}

Vreza Budi Setiawan, Ratna Dwi Wulandari

Fakultas Kesehatan Masyarakat, Universitas Airlangga, Surabaya

E-mail: vrezabudisetiawan@gmail.com

\begin{abstract}
In 2014 patient visits to pharmacy services increased 75\% from the previous year. Man power in the pharmacy unit was not comparable with the number of pharmacy service. The availability of human resources is inadequate when being compared to the number of outpatient pharmacy visits, therefore it influenced the respon time up to $43,91 \%$ for non paten drugs which as not in accordance with the standart services minimum pharmacy services. This data indicate that there was overload capacity on man power in outpatient pharmacy unit. The purpose of this study was to show wordload category on man power in outpatient pharmacy unit, particularly to pharmacists and assistants pharmacists. This was quantitative descriptive study. There were 26 samples consisting of 1 pharmacist, 16 asisstants pharmacists in depo 1 and 9 asisstants pharmacists in depo 5 outpatient pharmacy unit. Data collected by observation for 2 week in working hours. Result of the study was pharmacicts and assitants pharmacists in depo 1 had subjective and objective workload in overload category while depo 5 in moderate category.
\end{abstract}

Keywords: subjective and objective workload, pharmacicts and assitants pharmacists, work sampling

\section{PENDAHULUAN}

Menurut Undang-Undang Republik Indonesia Nomor 44 Tahun 2009, Rumah Sakit mempunyai tugas memberikan pelayanan kesehatan perorangan secara paripurna, yang memiliki fungsi penyelenggaraan pelayanan pengobatan dan pemulihan kesehatan sesuai dengan standar pelayanan Rumah Sakit, serta pemeliharaan dan peningkatan kesehatan perorangan. Berdasarkan surat Keputusan Menteri Kesehatan Republik Indonesia Nomor 1197/Menkes/SK/X/2004 Tentang Standar Pelayanan Farmasi Rumah Sakit menyebutkan bahwa pelayanan Rumah Sakit adalah bagian yang tidak terpisahkan dari sistem pelayanan kesehatan yang berorientasi kepada pelayanan pasien, penyediaan obat yang bermutu, termasuk pelayanan klinik yang terjangkau bagii semua lapisan masyarakat sehingga berdampak pada kepuasan pasien itu sendri.

Rumah Sakit X merupakan salah satu rumah sakit swasta bertipe B di Surabaya mempunyai tenaga kefarmasian pada pelayanan farmasi rawat jalan. Tenaga kefarmasihan yang di maksud yaitu tenaga apoteker dan asisten apoteker yang berjumlah 26 orang yaitu terdiri dari 1 tenaga apoteker dan 25 asisten apoteker untuk melayani pasien yang berkunjung ke pelayanan farmasi rawat jalan. Dalam peraturan Permenkes No.58 tahun 2014 tentang Standar Pelayanan Kefarmasian di Rumah Sakit, bahwa standar pelayanan kefarmasian di Rumah Sakit meliputi standar pengelolahan sediaan farmasi, alat kesehatan, bahan medis habis pakai serta pelayanan farmasi klinik. Pelayanan farmasi yang belum mencapai angka standar pelayanan minimal menunjukkan terjadi masalah 
dalam unit tersebut. Salah satu faktor penyebab pelayanan farmasi yang tidak mencapai standar yaitu semakin banyaknya kunjungan pasien ke pelayanan farmasi tetapi tidak didukung dengan SDM yang tersedia.

Pada tahun 2014 kunjungan pasien ke pelayanan farmasi rawat jalan mengalami peningkatan yang mencapai $75 \%$ dari tahun sebelumnya hal ini dikarenakan pada tahun tersebut pihak rumah sakit melakukan kerja sama dengan pihak asuransi kesehatan. Sedangkan SDM tersedia tidak sebanding dengan jumlah pelayanan resep pasien rawat jalan, yang berakibat pada tingginya beban kerja pada unit tersebut. Tingginya beban kerja tenaga apoteker dan asisiten apoteker di pelayanan rawat jalan juga menyebabkan response time tidak sesuai SPM yaitu pada pelayanan farmasi di depo 1 yaitu mencapai rerata $28 \%$ untuk obat racikan dan non racikan mencapai rerata $43.91 \%$, sehingga berpengaruh pada kualitas mutu pelayanan serta kepuasan pasien pada pelayanan kefarmasian. Hendrawan (2008) mengatakan bahwa Jika jumlah pekerja dalam suatu fungsi terlalu sedikit, maka beban kerja per orang akan tinggi. Akibatnya kualitas pelayanan akan rendah atau bahkan kinerja fungsi tersebut di bawah standar. Beban kerja tinggi ini juga menyebabkan produktifitas tenaga apoteker dan asisten apoteker menjadi rendah hal ini senada dengan Haryanti (2013) menyatakan bahwa beban kerja yang tinggi sangat berpengaruh terhadap produktifitas tenaga kesehatan dan tentu saja berpengaruh terhadap produktifitas tenaga apoteker dan asisten apoteker. Tenaga apoteker dan asisten apoteker merasakan bahwa jumlah SDM yang ada tidak sebanding dengan jumlah pekerjaan yang harus diselesaikan. Kondisi ini dapat memicu munculnya suatu masalah, karena semua pasien yang berkunjung secara tidak langsung menuntut mendapatkan pelayanan yang efektif dan efisien.

Penelitian ini bertujuan untuk mengetahui beban kerja pada tenaga apoteker dan asisten apoteker rawat jalan. Hasil dari penelitian ini diharapkan dapat menjadi bahan acuan untuk mengetahui beban kerja kerja pada tiap unit instalasi farmasi rawat jalan.

\section{PUSTAKA}

Beban kerja merupakan beban aktivitas fisik, mental, sosial yang diterima oleh seseorang yang harus diselesaikan dalam waktu tertentu, sesuai dengan kemampuan fisik, maupun keterbatasan pekerja yang menerima beban tersebut. Pengertian beban kerja adalah sekumpulan atau sejumlah kegiatan yang harus diselesaikan oleh suatu unit organisasi atau pemegang jabatan dalam jangka waktu tertentu (Mempan, 1997). Analisis beban kerja adalah penentuan jumlah tenaga kerja yang diperlukan untuk menyelesaikan pekerjaan dalam waktu tertentu atau proses penentuan jumlah jam kerja orang yang dibutuhkan untuk menyelesaikan suatu beban kerja tertentu dalam periode waktu tertentu. Menurut Marwansyah (2010), analisis beban kerja adalah proses untuk menentapkan jumlah jam kerja-orang yang dibutuhkan untuk merampungkan beban kerja dalam waktu tertentu. Analisis beban kerja bertujuan untuk menentukan 
berapa jumlah pekerja yang dibutuhkan untuk menyelesaikan suatu pekerjaan dan berapa beban yang tepat dilimpahkan kepada satu orang pekerja. Beban kerja ini dapat dilihat secara subyektif, yaitu dari sudut pandang atau menurut persepsi pekerja dan secara obyektif yaitu keadaan nyata yang ada di lapangan.

Beban kerja subjektif adalah ukuran yang dipakai dalam menjawab tentang beban kerja yang dilakukan, perasaan kelebihan beban kerja, dan ukuran dari tekanan serta kepuasan kerja (Rivai, 2003). Beban kerja subjektif meliputi persepsi terhadap beban fisik, mental, dan sosial (Koesyanto, 2008). Beban kerja fisik merupakan Pekerjaan yang dilakukan dengan mengandalkan kegiatan fisik semata akan mengakibatkan perubahan pada fungsi alat-alat tubuh. Beban kerja mental merupakan penilaian beban kerja yang berhubungan dengan tekanan perasaan atau mental selama berkerja (Muntiyani, 2010). Beban kerja sosial adalah penilaian terhadap beban yang berkaitan dengan individu lain yang dirasakan selama waktu kerja meliputi subjek yang terlibat dalam pekerjaan (Muntiyani, 2010).

Beban kerja objektif adalah keseluruhan waktu yang dipakai atau jumlah aktivitas yang dilakukan (Rivai, 2003). Beban kerja objektif adalah pengukuran terhadap beban kerja yang dinyatakan dalam bentuk proporsi penggunaan waktu kerja yang dibedakan atas beban kerja langsung, beban kerja tidak langsung, dan beban kerja lain-lain (Muntiyani, 2010). Beban kerja secara obyektif merupakan keadaan nyata yang ada di lapangan. Secara obyektif, beban kerja dilihat dari keseluruhan waktu yang dipakai atau jumlah aktivitas yang dilakukan beban kerja obyektif adalah pengukuran terhadap beban kerja yang ada di lapangan yang dinayatakan dalam bentuk proporsi penggunaan waktu kerja dibedakan atas beban kerja beban langsung, beban kerja tidak langsung, dan beban kerja lain-lain. International Labour Organization (ILO) hasil persentase (\%) diperoleh dari pembagian antara total waktu kegiatan produktif dengan 480 menit kemudian dikalikan $100,00 \%$, sehingga didapatkan kriteria: Bila waktu kerja produktif $>85,00 \%$ maka tergolong beban kerja berat, Bila waktu kerja produktif $75,00 \%$ sampai dengan $85,00 \%$ maka tergolong beban kerja sedang, Bila waktu kerja produktif $<75,00 \%$ maka tergolong beban kerja rendah.

Perhitungan beban kerja dapat dilakukan dengan 3 cara untuk melihat beban kerja personal yaitu mengunakan teknik work sampling, time motion study, daily log (llyas, 2004). Work sampling adalah pengukuran kegiatan kerja dari karyawan dengan cara melakukan pengamatan dan pencatatan, dimana jumlah sampel pengamatan kegiatan dilakukan secara random atau acak. Menurut llyas (2004) menyatakan terdapat beberapa tahap yang harus dilaksanakan dalam survey pekerjaan dengan menggunakan teknik work sampling, yaitu penentuan personel, peneliti mengamati semua staf yang bertugas, membuat formulir daftar kegiatan, pengamatan dilakukan dengan interval 2-15 menit. Analisis yang dihasilkan teknik work sampling ini yaitu informasi deskripsi jabatan, pola kegiatan, 
kesesuaian beban kerja dengan jenis tenaga. Time and motion study merupakan teknik pengamatan dan pengikutan dengan cermat tentang kegiatan yang dilakukan oleh SDM yang sedang diamati. Daily log atau pencatatan kegiatan sendiri merupakan bentuk sederhana dari work sampling, yaitu pencatatan yang dilakukan sendiri oleh SDM yang diamati. Pencatatan meliputi kegiatan yang dilakukan dan waktu yang diperlukan untuk melakukan kegiatan tersebut.

\section{METODE}

Penelitian ini merupakan penelitian deskriptif observasional yang pengambilan datanya secara cross sectional. Teknik pengambilan data mengunakan metode work sampling untuk mengukur beban kerja obyektif dengan pendekatan obsevasional. Sampling yang digunakan adalah seluruh populasi pada 2 depo farmasi rawat jalan yang ada di Rumah Sakit yang berjumlah 26 orang. Beban kerja subyektif diukur dengan menggunakan kuesioner beban kerja subyektif dari penelitian Dimantika pada tahun 2012 pada sample yang sama pada proses work sampling. Pengumpulan data dilakukan pada bulan juni sampai Juli tahun 2015 .

Beban kerja obyektif diukur dengan metode work sampling selama 12 hari kerja. Metode ini dilakukan secara obsevasi dengan mencatat seluruh kegiatan yang dilakukan oleh tenaga apoteker dan asisten apoteker selama interval 5 menit pada masing-masing shif. Kegiatan dibedakan menjadi jenis kegiatan produktif dan kegaiatan non produktif. Sehingga, didapatkan kategori menjadi beban kerja obyektif tinggi hingga rendah yaitu (tinggi $>85 \%$, sedang $75-85 \%$, rendah $<75 \%$ ).

Beban kerja subyektif pengambilan datanya peneliti mengunakan kuesioner beban kerja subyektif. Data yang diperoleh dari kuesioner beban kerja subyektif terlebih dahulu dilakukan skoring, kemudian dikategorikan menjadi beban kerja subyektif sangat ringan hingga tinggi yaitu, (sangat ringan $0-0.9$, ringan $1.00-1,99$, sedang $2,00-2,99$, berat $3,00-3,99$, tinggi $4,00-4,99$ ). Hasil dari beban beban kerja subyektif dan obyektif selanjutnya akan dibandingkan untuk melihat ketidaksesuaian beban kerjanya.

\section{HASIL DAN PEMBAHASAN}

\section{Beban kerja subyektif}

Beban kerja subjektif adalah ukuran yang dipakai dalam menjawab tentang beban kerja yang dilakukan, perasaan kelebihan beban kerja, dan ukuran dari tekanan serta kepuasan kerja. Beban kerja subjektif meliputi persepsi terhadap beban fisik, mental, dan sosial. Beban fisik merupakan penilaian pegawai terhadap semua tugas dan pekerjaan yang harus dilaksanakan selama jam kerja, persepsi ini meliputi Penilaian terhadap jumlah tugas, Penilaian terhadap waktu kerja dan Penilaian terhadap kecukupan tenaga kefarmasian Rumah Sakit. Beban kerja mental merupakan penilaian beban kerja yang berhubungan dengan tekanan perasaan atau mental selama berkerja. Beban kerja sosial adalah penilaian terhadap beban yang berkaitan dengan individu lain yang dirasakan selama waktu kerja meliputi subjek yang terlibat dalam pekerjaan (Muntiyani, 2010). 
Tabel 1. Beban Kerja Subyektif berdasarkan aspek (Fisik, Mental, Sosial) Berdasarkan Kategori Beban Kerja Subuektif

\begin{tabular}{|c|c|c|c|c|c|c|c|c|c|c|c|c|}
\hline \multirow{3}{*}{ Aspek Beban Kerja } & \multicolumn{10}{|c|}{ Ketegori Beban Kerja Subyektif } & \multirow{2}{*}{\multicolumn{2}{|c|}{ TOTAL }} \\
\hline & \multicolumn{2}{|c|}{ Sangat Ringan } & \multicolumn{2}{|c|}{ Ringan } & \multicolumn{2}{|c|}{ Sedang } & \multicolumn{2}{|c|}{ Berat } & \multicolumn{2}{|c|}{ Tinggi } & & \\
\hline & $\Sigma$ & $\%$ & $\Sigma$ & $\%$ & $\Sigma$ & $\%$ & $\Sigma$ & $\%$ & $\Sigma$ & $\%$ & $\Sigma$ & $\%$ \\
\hline \multicolumn{13}{|l|}{ Apoteker } \\
\hline Fisik & 0 & 0 & 0 & 0 & 0 & 0 & 1 & 100 & 0 & 0 & 1 & 100 \\
\hline Mental & 0 & 0 & 0 & 0 & 0 & 0 & 1 & 100 & 0 & 0 & 1 & 100 \\
\hline Sosial & 0 & 0 & 0 & 0 & 0 & 0 & 1 & 100 & 0 & 0 & 1 & 100 \\
\hline \multicolumn{13}{|l|}{ Asisten Apoteker Depo 1} \\
\hline Fisik & 0 & 0 & 2 & 12,5 & 6 & 37,5 & 4 & 25 & 4 & 25 & 16 & 100 \\
\hline Mental & 0 & 0 & 3 & 18,7 & 5 & 31,2 & 4 & 25 & 4 & 25 & 16 & 100 \\
\hline Sosial & 0 & 0 & 2 & 12,5 & 3 & 18,7 & 9 & 56,2 & 2 & 12,5 & 16 & 100 \\
\hline \multicolumn{13}{|l|}{ Asisten Apoteker Depo 5} \\
\hline Fisik & 0 & 0 & 3 & 33,3 & 3 & 33,3 & 2 & 22,2 & 1 & 11,1 & 9 & 100 \\
\hline Mental & 0 & 0 & 3 & 33,3 & 5 & 55,5 & 1 & 11,1 & 0 & 0 & 9 & 100 \\
\hline Sosial & 0 & 0 & 3 & 33,3 & 2 & 22,2 & 3 & 33,3 & 1 & 11,1 & 9 & 100 \\
\hline
\end{tabular}

Hasil dari beban kerja subyektif pada tenaga apoteker rawat jalan mengatakan berat. Hal ini disebabkan antara lain karena apoteker merasa terbebani dengan jumlah apoteker yang tidak sebanding dengan rata-rata jumlah pelayanan pasien rawat jalan dalam pelayanan farmasi yang rerata tiap hari hampir 350 lembar resep yang harus dilayani sehingga menjadikan tugas sangat banyak dalam bekerja serta tambahan tugas untuk semua depo rawat jalan menjadi tangung jawab 1 apoteker rawat jalan hal ini diperjelas bahwa adanya ketidaksesuain menurut peraturan bahwa 1 tenaga apoteker melayani 50 pasien tiap harinya (Permenkes No.58 2014). Sehingga tenaga apoteker meresa terbani dalam melakukan pekerjaannya. Hal ini juga senada dengan Haryanti (2013) mengatakan bahwa jumlah SDM yang ada tidak sebanding dengan jumlah pekerjaan yang harus diselesaikan menjadikan beban kerja tinggi. Kondisi ini dapat memicu munculnya suatu masalah, karena semua pasien yang berkunjung secara tidak langsung menuntut mendapatkan pelayanan yang efektif dan efisien.

Pada depo 1 hasil beban kerja subyektif mayoritas mengatakan kategori beban kerja subyektif berat hal ini dikarenan banyaknya pelayanan resep tetapi tidak diimbangi dengan penambahan SDM serta tugas administrasi yang berat menjadi tanggungjawab masing-masing staf menjadikan beban kerja fisik menjadi berat. Penyataan diatas senada dengan penyataan (Samba, 2000) bahwa beban kerja tenaga kesehatan seperti tenaga apoteker dan asisten apoteker dipengaruhi beberapa faktor yaitu perbandingan jumlah tenaga dan jumlah pasien, faktor keterampilan manajemen atau pengalaman kerja dan faktor tingkat pendidikan. Pada beban kerja subyektif mental tenaga asisten apoteker mengalami kejenuhan serta kelelahan terhadap banyaknya tugas yang harus diselesaikan selain tugas 
pelayanan dan terkadang pekerja mengalami kondisi stres dalam bekerja saat melayani pasien yang berbeda karakteristik (Kasmarani, 2012). Sehingga menjadikan pekerjaan menjadi berat contohnya saat penjelasan resep atau saat pelayanan resep terkadang pasien marah karena terlalu lama menunggu. Pada beban kerja subyektif sosial tenaga asisten apoteker mengatakan berat $\mathrm{Hal}$ ini disebabkan antara lain tenaga asisten apoteker depo 1 merasa terbebani dengan adanya masalah yang timbul dengan rekan sesama tenaga farmasi ketika melakukan pekerjaan. Sebagai seorang manusia yang sebagai makhluk sosial yang membutuhkan rekan sesamanya ketika melakukan suatu pekerjaan yang menjadi tugas rutin dan tanggung jawabnya setiap harinya. Beban kerja subjektif yang tinggi dapat menurunkan berat badan karena adanya gangguan psikologis. Hal ini senada dengan pernyataan Tarwaka (2004) bahwa stres sebagai akibat ketidakserasian emosi, hubungan manusia dalam pekerjaan yang kurang baik, rangsangan atau hambatan psikologis, sosial, dan lain-lain akan menurunkan berat badan, terjadinya penyakit dan tidak produktifnya tenaga kerja sehingga untuk mencapai optimalisasi kinerja apoteker dan asisten apoteker maka tuntutan tugas harus seimbang dengan kapasitas kerjanya

Sedangkan pada depo 5 mayoritas tenaga asisten apoteker mengatakan beban kerja sedang. Hal ini dikarenakan jumlah pelayanan dalam depo 5 relatif sedikit jika dibandingkan jumlah SDM sehingga menjadikan pekerjaan yang ditangani tidak menjadikan beban bagi pekerja. Hal tersebut senada dengan pernyataan (Tarwaka 2004) bahwa tuntutan tugas lebih rendah dari pada kemampuan atau kapasitas kerjanya maka akan terjadi penampilan akhir berupa understress, kebosanan, kejemuan, kelesuan.

Hal tersebuat senada dengan Rodahl (2000) bahwa faktor yang memperngaruhi beban kerja yaitu Lingkungan kerja psikologis seperti pemilihan dan penempatan tenaga kerja, hubungan antara pekerja dengan pekerja, pekerja dengan atasan, pekerja dengan keluarga dan pekerja dengan lingkungan sosial yang berdampak kepada performasi kerja di tempat kerja.

\section{Beban kerja obyektif}

Menurut Barnes (1980), work sampling adalah pengukuran kegiatan kerja dari karyawan dengan cara melakukan pengamatan dan pencatatan, dimana jumlah sampel pengamatan kegiatan dilakukan secara random atau acak. Beban kerja secara obyektif merupakan keadaan nyata yang ada di lapangan. Secara obyektif, beban kerja dilihat dari keseluruhan waktu yang dipakaii atau jumlah aktivitas yang dilakukan. Menurut Gibson (2000), beban kerja obyektif adalah pengukuran terhadap beban kerja yang ada di lapangan yang dinyatakan dalam bentuk proporsi penggunaan waktu kerja dibedakan atas beban kerja beban langsung, beban kerja tidak langsung, dan beban kerja lain-lain. Berikut ini adalah hasil pengamatan beban kerja obyektif menggunakan work sampling responden tenaga apoteker dan asisten apoteker di Depo Farmasi Rawat Jalan pada shif pagi dan shif siang. 
Tabel 2. Beban Kerja Obyektif Berdasarkan Penggunaan Waktu Kerja dengan Metode Work sampling

\begin{tabular}{lcccc}
\hline \multicolumn{1}{c}{ Tenaga Farmasi } & Shift & $\begin{array}{c}\text { Rerata Waktu Produktif } \\
\text { Perhari (Menit) }\end{array}$ & Presentase & $\begin{array}{c}\text { Kategori Beban } \\
\text { Kerja Obyektif }\end{array}$ \\
\hline Apoteker & Pagi & 422 & $87,91 \%$ & Berat \\
\hline Asisten Apoteker Depo 1 & Pagi & 426 & $88,75 \%$ & Berat \\
\cline { 2 - 5 } Asisten Apoteker Depo 5 & Siang & 440 & $91,67 \%$ & Berat \\
\cline { 2 - 5 } & Pagi & 285 & $59,38 \%$ & Rendah \\
\hline
\end{tabular}

Pada beban kerja obyektif tenaga apoteker rawat jalan memiliki beban kerja objektif tinggi (penggunaan waktu produktif $>85,00 \%)$ ) sebesar $87,91 \%$. Hal ini dikarenakan tugas administrasi rawat jalan, pemantauan kegiatan pelayanan, monitoring obat dan evaluasi mutu pelayanan seluruh depo rawat jalan menjadi tangung jawab satu apoteker sehingga beban kerja untuk apoteker menjadi tinggi.

Pada tenaga asisten apoteker mayoritas mengatakan beban kerja berat pada shif siang terutama pada depo 1. Hal ini dikarenakan tugas pokok yang dikerjakan sangat banyak serta adannya ketidakseimbangan tenaga asisten apoteker dengan jumlah resep yang terjadi lonjakan yang signifikan sejak adanya kerjasama asuransi kesehatan di tahun 2014 tetapi tidak di tambahkan jumlah kebutuhan SDM sesuai dengan jumlah pelayanan yang masuk dalam depo 1 farmasi rawat jalan. Sedangkan sistem pelayanan yang kurang baik dalam melakukan aktifitas pelayanan menjadi salah satu masalah yang berakibat pada tingginya beban kerja. Sehingga perlu adanya evaluasi penambahan kebutuhan SDM sesuai dengan jumlah pelayanan yang diberikat setiap waktu tertentu dan perubahan sistem pelayanan sehingga lebih meningkatkan mutu pelayanan pada depo tersebut. Serta banyaknya praktek dokter pada shift siang dibanding shift pagi juga menjadikan mengapa beban kerja tinggi pada shif siang, sehingga pelayanan resep pasien juga bertambah. Sehingga bisa dikatakan bahwa pada shif siang aktifitas fisik lebih banyak dari shif pagi untuk kegiatan produktifnya.

Normalnya orang bekerja pada pagi sampai sore hari sedangkan menjelang malam hari dilakukan untuk istirahat mengumpulkan tenaga. Sehingga terjadinya interaksi yang berlebihan yang memberikan beban kerja yang tinggi pada tenaga asisten apoteker pada shif siang. Sehingga mengakibatkan tenaga asisten apoteker terkadang dalam kondisi jenuh dan stres dalam melaksanakan tugasnya pada shif siang. Hal ini senada dengan pendapat (Mudayana, 2012) Apabila beban kerja yang diterima terlalu besar maka akan dapat menimbulkan stress kerja yang bisa mempengaruhi motivasi kerja dan menurunnya kinerja, selain itu juga dapat mempengaruhi pelayanan kepada pasien serta kepuasan pasien sehingga kinerja tenaga asisten apoteker menjadi rendah.

Meskipun tenaga asisten apoteker di Instalasi Rawat Jalan terbiasa dengan beban kerja tinggi, tidak berarti pihak rumah sakit hanya bisa diam saja akan kondisi tersebut. Dengan adanya beban yang 
tinggi kerja tiap hari dapat memberikan dampak pada tenaga asisten apoteker tersebut dikemudian hari, karena tidak selamanya daya tahan tubuh manusia akan selalu bertahan pasti akan terjadi penurunan daya tahan tubuh. Beban kerja yang terlalu berlebihan akan menimbulkan berbagai efek yakni kelelahan baik fisik maupun mental dan reaksi-reaksi emosional seperti sakit kepala, gangguan pencernaan, kelalaian, lupa dan mudah marah sehingga secara potensial membahayakan pekerja atau tenaga asisten apoteker (Prihatini, 2007)

\section{Analisis Beban Kerja Subyektif dan Obyektif}

Berikut ini merupakan analisis hasil beban kerja subyektif dan beban kerja obyektif pada tenaga apoteker dan asisten apoteker setiap unit kerja pada Instalasi Farmasi Rawat Jalan di Rumah Sakit X Surabaya Tahun 2015.

Tabel 3. Analisis Beban Kerja Subyektif Dan Obyektif Tenaga Apoteker dan Asisten Apoteker Rawat Jalan.

\begin{tabular}{lcc}
\hline \multicolumn{1}{c}{ Tenaga Farmasi } & Beban Kerja Subyektif & Beban Kerja Obyektif \\
\hline Apoteker & Berat & Berat \\
\hline Asisten Apoteker Depo 1 & Berat & Berat \\
\hline Asisten Apoteker Depo 5 & Sedang & Rendah \\
\hline
\end{tabular}

Pada Tabel 3 Dari hasil beban kerja pada tenaga apoteker jika dilihat dari subyektif dan obyektif mengatakan sama-sama kategori berat hal ini dikarenakan pada antara lain besarnya tangung jawab diseluruh proses pelayanan depo farmasi rawat jalan, baik tugas pokok maupun tugas adminstrasi diselesaikan hanya pada satu apoteker. Pada depo 1 farmasi rawat jalan mengatakan beban kerja kategori berat baik dilihat dari beban kerja subyektif dan obyektif. Salah satu penyebab pada depo 1 mengatakan beban kerja berat adalah tidak seimbangnya antara jumlah SDM dengan pelayanan resep yang masuk sehingga perlunya penambahan tenaga asisten apoteker pada depo1. Serta tugas administrasi yang menjadi tangung jawab masingmasing tenaga asisten apoteker dirasa berat hal ini dikarenakan bnyaknya laporan yang harus dikerjakan sebagai laporan kepada pihak jaminan kesehatan, hal ini berakibat pada pekerjaan yang berlebih sehingga menjadikan kelelahan serta penurunan motivasi kerja (Hariyono, 2009). Pada depo 5 beban kerja subyektif maupun obyektif mengatakan ketegorii sedang dan rendah hal ini dikarenakan pada depo 5 pelayanan relatif sedikit.

Dapat dilihat hasil penelitian mengenai beban kerja subyektif maupun obyektif setiap unit kerja, bahwa hasilnya sangat berbeda setiap unit kerja. Ada unit kerja dengan beban kerja yang rendah hingga berat. Sehingga dapat disimpulkan bahwa data tersebut memberikan gambaran manajemen Rumah Sakit bahwa ada perbedaan beban kerja antar bagian. Hal ini perlu dilakukan analisis lebih lanjut untuk mengetahui hal-hal yang menyebabkan perbedaan tersebut. Berdasarkan hasil beban kerja pada setiap unit kerja, maka langkah selanjutnya dilakukan perhitungan kebutuhan SDM sesuai dengan beban kerjanya pada setiap unit.

\section{SIMPULAN}

Hasil penelitian menunjukan bahwa terdapat perbedaan beban kerja pada masing-masing unit kerja. Pada tenaga apoteker rawat jalan memiliki 
beban kerja berat, hal ini disebabkan besarnya tangungjawab semua depo rawat jalan atau pelayanan rawat jalan hanya pada 1 tenaga apoteker. Pada tenaga asisten apoteker depo 1 memiliki kategori beban kerja subyektif berat dan obyektif tinggi, hal ini dikarenakan tidak sesuainya jumlah SDM tersedia jika dibanding dengan jumlah pelayanan pasien. Pada depo 5 tenaga asisten apoteker memiliki beban kerja subyektif rendah dan obyektif sedang, hal ini dikarenakan jumlah pelayanan pasien relatif sedikit.

Rumah sakit perlu melakukan pengaturan kembali sistem keseimbangan antara jumlah tenaga SDM dan beban kerja. Sehingga dalam membuat suatu pelayanan harus benar-benar diperhitungkan baik kuantitas maupun kualitas. Berdasarkan kebutuhan waktu kerja per hari, masih ada ketidakseimbangan beban kerja antar unit kerja. Hal ini perlu dilakukan analisis lebih lanjut agar tidak terjadi perbedaan yang dapat menimbulkan kecemburuan sosial yang pada akhirnya dapat menurunkan produktivitas kerja.

Bagi peneliti lain yang akan melakukan penelitian semacam ini perlu disarankan melakukan penelitian dengan memperhatikan kualitas pekerjaan setiap tenaga apoteker dan tenaga apoteker.

\section{DAFTAR PUSTAKA}

Bambang, H. (2008). Pengukuran dan Analisis Beban Kerja Pegawai Bandara Hang Nadim. Vol 1; no.1; hal 1-11. Jurnal managemen bisnis $P B N$.

Hariyono, (2009). Hubungan Antara Beban Kerja, Stress Kerja, Dan Tingkat Konflik Dengan Kelelahan Kerja Perawat Di Rumah Sakit Islam Yogyakarta PDHI. Vol 3; edisi 3; hal 186-197. Jurnal Kesmas UAD

Haryanti, (2013). Hubungan Antara Beban Kerja Dengan Stres Kerja Perawat Di Instalasi
Gawat Darurat Rsudkabupaten Semarang. Vol 1; no.1; hal 1-9. Jurnal Manejemen keperawatan PPNI

llyas, Y. (2004). Perencanaan SDM Rumah Sakit: Teori, Metoda dan Formula. Edisi revisi. Depok: Pusat Kajian Ekonomi Kesehatan Fakultas Kesehatan Masyarakat-Universitas Indonesia.

Kasmarani, M.K. (2012). Pengaruh Beban Kerja Fisik dan Mental Terhadap Stres Kerja pada Perawat di Instalasi Gawat Darurat (IGD) RSUD Cianjur. Vol I; edisi 3; hal 767-776 Jurnal Kesehatan Masyarakat.

Koesyanto, H. (2008). Hubungan Antara Beban Kerja dengan Kelelahan Kerja Mengajar Pada Guru Sekolah Dasar Se-Kecamatan Semarang Barat tahun Ajaran 2006/2007. Vol; 3 edisi; 1. Jurnal Kesmas Unnes.

Muntiyani. (2010). Analisis Pengaruh Beban Kerja Terhadap Kepuasan Kerja Perawat di Instalasi Rawat Inap Rumah Sakit Jiwa Menur. Skripsi. Surabaya: Universitas Airlangga.

Republik inodensia (2014). Permenkes RI Nomor 58 Tahun 2014 Tentang Standar Pelayanan Kefarmasian di Rumah Sakit. Jakarta: Kementrian Kesehatan RI

Rivai, F. (2003). Faktor Dominan yang Mempengaruhi Kinerja Perawat dalam Melaksanakan Asuhan Keperawatan di Ruang Rawat Inap RSUD Haji Subaraya. 2003. Vol; 1(3), Hal; 167-168. Jurnal Administrasi Dan Kebijakan Kesehatan.

Rodahl, (2000). dalam Manuaba. Hubungan Beban Kerja dan Kapasitas Kerja. Jakarta. Rineka Cipta.

Samba, S. (2000). Pengantar Kepemimpinan dan Manajeman Keperawatan Untuk Perawat Klinis. Jakarta: ECG.

Setiawan, V. B. (2015). Analisis Perhitungan Kebutuhan Tenaga Apoteker dan Asisten Apoteker Berdasarkan Workload Analysis Dengan Metoe WISN (Studi di Instalasi Farmasi Rawat Jalan Rumah Sakit Islam Jemursari Surabaya). Skripsi. Surabya: Universitas Airlangga.

Tarwaka, (2004). Ergonomi untuk Keselamatan Kesehatan Kerja dan Produktivitas. Surakarta: UNIBA Press, Universitas Islam Surakarta.

Republik Indonesia. (2009). Undang-Undang RI No. 44 Tahun 2009 Tentang Rumah Sakit. Jakarta: Sekretariat Negara RI.

Republik Indonesia. (2004). Keputusan menteri kesehatan RI No.1197 Tahun 2004 Tentang Standar Pelayanan Farmasi. Jakarta: Kementerian Kesehatan RI.

Republik Indonesia. (2014). Peraturan Menteri Kesehatan RI No. 58 Tahun 2014 Tentang Standar Pelayanan kefarmasihan. Jakarta: Kementerian Kesehatan RI. 